\title{
Sharia accounting on Indonesian Financial Accounting Standard on zakat and waqf take on industrial revolution 4.0 and society era 5.0
}

\author{
Agus Arwani \\ Institut Agama Islam Negeri Pekalongan, Indonesia \\ email: agus.arwani@iainpekalongan.ac.id
}

\begin{abstract}
Purpose - The aims to point out the challenges and expectations towards sharia accounting profession on zakat and waqf in facing the industrial revolution.
\end{abstract}

Method - This research used a qualitative approach by systematically explaining various sources of literature.

Result - The results of the research shows that the era of the Industrial Revolution 4.0 and Society 5.0 offers convenience and speed, making people turn into super fast and human-centered. Both professional and sharia accountants need a pattern of self-management on the basic functions of sharia accounting which will, in turn, increase the efficiency and effectiveness of their work and the results can be shown in real-time.

Implication - Research implication shows that some companies have developed this because of the support gained from the adequate standardization of financial management processes and standardization information systems architecture and by the demands of the fourthgeneration industry proving that crucial competencies are needed for sharia accountants of zakat and waqf.

Originality - The research shows that Islamic accountants must understand Indonesian Financial Accounting Standard 109 on Zakat, Infaq and Sadaqah, and Indonesian Financial Accounting Standard 112 on Waqf which is based on information technology in the era of Industrial Revolution 4.0 and Society Era 5.0.

Keywords: sharia acoounting; zakat; waqf; industrial revolution

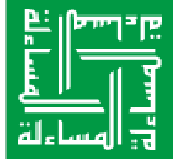

Journal of Islamic Accounting and Finance Research 


\section{Introduction}

The industrial revolution is at its peak today, following the birth of digital technology massively impacting human life throughout the world. The fourth

JIAFR | 230 generation of industrial revolution is driving automation in all activity processes (Ristekdikti, 2018a). The increasingly massive internet technology not only connects millions of people around the world but also becomes the foundation for online trade and transportation transactions (Kemenristekdikti, 2018a). The emergence of online transportation businesses such as Gojek, Uber and Grab shows that the integration between human activities, information technology, and the economy is increasing. The vast development of autonomous vehicle technology, drones, social media applications, biotechnology, and nanotechnology confirms that the world along with human life has fundamentally changed (Kemenristekdikti, 2018b).

The world is changing rapidly as a result of information and technology development. The phenomenon is acknowledged by sociologists as the era of disruption. An era in which all sectors; namely the field of economics, accounting, politics, and education, are affected by the transformation of information and technology (Harto, 2018).

The rapid development of science and information technology is encouraging research in various fields to be conducted to create sustainable benefits for humanity. As the consequence, various industries must prepare themselves and adapt to the development of information technology, if they do not want to be left behind and suffer financial loss (Purwandini \& Irwansyah, 2018).

The rapid development of information technology is the marking of the sophisticated era known as the industrial era 4.0, in which technology is projected to dominate all aspects of human life; including the industrial world. Industry 4.0 is a technological revolution concept based on continuous communication via the Internet that allows interaction and exchange of information, not only between humans but also between humans and machines and between the machines (Cooper et al., 2009). 
The industrial revolution includes a fundamental change in the way of human life and work processes, where the advancement of information technology integrates digitalization in life which affects the scientific disciplines. The emergence of the Industrial Revolution 4.0 creates a new stage in the phase of technological progress (Budiman, 2019).

JIAFR | 231

Whereas Society 5.0 is defined as a human-centered society that balances economic progress with the resolution of social problems through system deeply integrating virtual space and physical space (Hamdan, 2018).

The four main components in industry 4.0 are Cyber-physical systems (connections between the real world and virtual world), the Internet of Things (IoT), the Internet of Services (IoS), and Smart- factories (Roblek et al., 2016). Internet of Things (IoT) is a structure in which objects and people are given an exclusive identity and the ability to move data in a network without involving human interactions directly, such as the relationship of data sources to the destination (directly, without human assistance) or human interaction with computers (Burange \& Misalkar, 2015). Internet of Things (IoT) is a very promising scientific development to optimize life based on smart sensors and smart equipment working together through the internet network (Keoh et al., 2014). Whereas Smart-Factory is a concept in which the manufacturing system will be equipped with sensors, actors, and autonomous systems. Machines have their optimized capabilities and can "make decisions" autonomously (Niemueller et al., 2017).

What happens in industry 4.0 is the automation and digitalization of all aspects of the industry to create products that can satisfy the need of consumers. Human intervention or manual activity will be reduced by the presence of advanced technology. It includes managing customer data which are directly obtained from customers and are analyzed and stored in the cloud, as well as the unlimited exchanging of information between people and objects through wireless communication networks (Roblek et al., 2016). It is imperative that accounting and sharia-based accounting be prepared to face a new era. Sharia accounting which appears to be very strategic and thriving in past decade will, however, have to keep up with the developments in 
information technology, ranging from banking, business, product, insurance, self-service, to educational institutions are starting to participate in using the Sharia label. It is also applied in the accounting sector (Arwani, 2017).

Based on the concept of modern accounting, it is neutral, free of value, and free from any interests (value free) (Nugroho dkk, 2020). Then what is taught in the education of accounting? Is accounting free of value, is it neutral? Reflecting deeper upon the matter, we will surely find discrepancies. As an example, the accounting value may not be free, because the manufacturing process involves human individuals who have different personalities and full of interest (Triyuwono, 2006b)(Sari et al., 2016).

Sharia accounting is present to deconstruct accounting with modern ideologies (Triyuwono, 2000). Through epistemology, sharia accounting seeks to contribute to accounting as an instrument used in business activities as well as as a medium in discovering the nature of human life goals. With a human being able to know the nature of their purpose in life, expectations can surely be fulfilled, rules are set and they will certainly be a law-abiding person, because their attitude is better or above all the rules (Ather \& Ullah, 2009). In another point of view, religious people must obey laws and other rules made by humans and can keep up with developments in information technology (Arwani, 2018).

The Indonesian Institute of Accountants (Ikatan Akuntan Indonesia/IAI) as a professional accountant organization in Indonesia is trying to contribute to achieve good accounting system of a Zakat Management Organization (ZMO). In 2010, IAI issued Statement of Financial Accounting Standards (Indonesian Financial Accounting Standard/IFAS) No. 109. This IFAS claims to regulate the accounting for zakat, infaq and sadaqah which standardizes the recognition, measurement, presentation and disclosure of zakat and infaq/sadaqah transactions applicable to zakat managers who are obliged to abide and distribute zakat and infaq/sadaqah. The IFAS is issued as standardization guidelines in recording transactions and preparing financial reports made by the ZMO. With this standardization, there will be uniformity and comparability in financial recording and reporting made by the ZMO in 
Indonesia, which can also help facilitate public accountants in auditing the ZMO financial statements (Rahman, 2015).

The IFAS 112 of Accounting for Waqf states that the waqf entity recognizes the receipt of waqf assets from the wakif (initial waqf assets) only if the waqf entity has legal and physical control over the assets. The requirements for the recognition of initial waqf assets in the financial statements are the transfer of control over the assets from waqf to the waqf entity with both conditions fulfilled, such as a) there has been a legal transfer of control over the waqf assets; and $b$ ) there has been a transfer of control over the economic benefits of the waqf assets. The above conditions will generally be fulfilled when a waqf pawning deed occurs-that is when there is a transfer of control over the waqf assets legally-accompanied by the transfer of physical control over the assets from wakif to the entity. Legal control over waqf assets can also be fulfilled, for example, when wakif transfers the fund directly to the accounts of the waqf entity through a financial institution (Arifson, 2020).

In terms of presentation, it is explained that the waqf entity presents the temporary waqf assets received as a liability because it must be adjusted to the time of recognition that the entity is required to return the waqf assets to the waqf in the future (Yollanda \& Adnan, 2018).

According to that, the role of sharia accountants in the era of the industrial revolution 4.0 is to understand the IFAS 109 on the Accounting for Zakat and Sadaqah giving and IFAS 112 on Accounting for Waqf. Therefore, there is a special role for sharia accountants in understanding IFAS 109 and 112 in the era of the Industrial Revolution 4.0, which distinguishes it from the previous researches.

\section{Literature Review}

\section{The Concept of Industrial Revolution 4.0 and Society 5.0}

According to Prof. Klaus Martin Schwab, German technician and economist, who is also the founder and Executive Chairman of the World 
Economic Forum, in his book The Fourth Industrial Revolution (2017), we are at the beginning of a revolution that fundamentally changes the way of life, work, and connection to one another. The change is very dramatic and occurs at an exponential speed (Ghufron, 2018).

There is a drastic change compared to the previous industrial revolution era. In the Industrial Revolution 1.0, the growth of steam and water-based mechanization and energy became a marker. Human and animal power was replaced by the emergence of machines. The steam engine in the 18th century was one of the highest achievements. This 1.0 revolution increased the economy's extraordinary. During the two centuries after the industrial revolution, the per capita income of countries in the world increased six times (Prasetyo \& Trisyanti, 2019).

The word "industry 4.0" appeared in 2011 at the Hannover Fair and in 2013 at the same event when a working group was formed, led by Siegfried Dais (Robert Bosch $\mathrm{GmbH}$ ) and Henning Kagermann (German Academy of Sciences and Engineering). The design principles used are divided into four parts, namely (1) Interconnection. Interpreted as the ability of machines, tools, sensors, and humans as users which are connected using the Internet of Things (IoT) or the Internet of People (IoP); (2) Information transparency. Clarity of information obtained is used as well as a decision-making tool; (3) Technical Assistance. Divided into two-the ability to visualize problems occurring and the ability to carry out tasks in areas dangerous to humans or workers. (4) Decentralized decisions. The ability of the system to make their own decisions and complete tasks simultaneously or continuously (Iswanto \& Wahjono, 2019).

The Industrial Revolution 4.0 gave birth to massive desperation resulting in intense competition in various fields, such as politics, economics, accounting, education, social, and religious dogma. The six points that drive the emergence of desists are technology, the millennial generation, microprocessor speed, disruptive leader, changes in winning, and the Internet of things. Renald Kasali explained that the millennial generation's movement in response to the Industrial Revolution 4.0 was like a snowball that 
continued to build its form, increasingly larger and without limits (Setiawan et al., 2018).

Industrial Revolution 4.0 offers a variety of conveniences such as being cheap, fast, and without limit. Human existence in maintaining socioeconomic routines began to face massive global changes. The accelerating changes in internet technology, artificial intelligence, and big data have encouraged each party to be able to compete in achieving a better life. The government continues to strive to achieve global targets in technology, social, political, economic, and accounting (Agung, 2013).

Francis Fukuyama in his book, The Great Disruption: Human Nature and the Reconstitution of Social Order, explains that the transformation of society from an agricultural society into an industrial society has brought a broad influence of social change in human history, which he called the great disruption (Fukuyama, 2017). As can be seen through its causes, such as poverty and inequality, increasing wealth led to the first conditions, the emergence of a modern welfare state, and extensive cultural shifts including the collapse of religion (Hurst et al., 2016).

The modern capitalist society, according to Fukuyama, tends to destroy the power of social capital in society. Development of countries or industries has ignited the power of social capital without having the ability to rebuild it (Setiawan et al., 2018).

The Industrial Revolution 4.0 which was considered to have the potential to degrade the role of humans caused Japan to give birth to a concept namely Society 5.0. Through this concept, it is hoped that artificial intelligence will transform big data collected through the Internet in all areas of life into new wisdom, with the hope of increasing human ability to open up opportunities. The comparison of these two concepts, that is in industry 4.0, people search, quote, and analyze DTA or information by accessing cloud services via the Internet (Mayasari, 2019).

Meanwhile, in Society 5.0 a large amount of information from sensors in physical space is accumulated in cyberspace and analyzed by artificial 
intelligence with the results reported back to humans in physical space in various forms (Budiman, 2019).

Taufikur Rohman's research result explains that a proper accounting and financial reporting system can help achieve transparency and accountability of an ZMO. In order to get a good and correct accounting and financial reporting system and to create uniformity and comparability in financial reporting so that ZMO is ready to be audited by a public accountant, the bookkeeping activities and preparation of ZMO financial statements must refer to a guideline or standard of zakat, infaq and sadaqah (ZIS) accounting. The current accounting standard for ZIS in Indonesia is the IFAS No. 109 on the accounting for zakat, infaq and sadaqah issued by the Indonesian Institute of Accountants (IAI). IFAS 109 is used as a guideline for ZMO in the recognition, measurement, presentation and disclosure of zakat, infaq and sadaqah transactions (Rahman, 2015).

Sabrina Shahnaz's research result stated that the National Board of Zakat (Badan Amil Zakat Nasional/BAZNAS) of North Sulawesi has not prepared financial statements in accordance with IFAS No. 109. BAZNAS can only provide an archive of reception and distribution of fund, when they should be preparing statements of financial position, statement of changed fund, statement of changed asset statement of cash flows and notes to the financial statements (Shahnaz, 2016).

Indria Puspitasari Lenap's research result stated that all of Sharia Banks being observed over the period of 2015-2017 had disclosed its nonhalal fund in financial statement according to Sharia Accounting Standard no. 109 , eventhough there was a lack of information about the detail amount of each transactions. (Lenap, 2019)

Arifson's research used descriptive methods in its data analysis, in which the author presented the financial statements of the Yayasan Wakaf Indo AsSakinah Al-Mawaddah Pekanbaru City which is not in accordance with IFAS 112 and with principles generally accepted in Islamic accounting (Arifson, 2020). 
Ucik Nadiyatul Islamiyah's research result stated that Nazhir Universitas Airlangga has implemented financial reports in accordance to IFAS 112 on recognition, measurement, presentation which includes statements of financial position, detailed reports of assets, and cash flow reports. However, the activity reports and notes to the financial statements have not fully implemented IFAS 112. The constraints experienced by Nazhir are the financial statements that only describe the results obtained by Nazhir in developing waqf funds and IFAS 112 does not reflect the social benefits of the waqf funds (Islamiyah, U.N, 2020).

\section{Industrial Revolution 4.0 and Disruption}

Globalization shows that any change in the future has its respective core (driver). Friedman, Ritzer, and Toffler's description shows that the movement of change is always triggered by technological developments that gave birth to the era of the Industrial Revolution 4.0, which not only opens wide interactions but also disrupts various aspects of human life (Mustaqim \& Bahruddin, 2015).

Disruption was originally a phenomenon that occurred in the economic world, especially in the business sector. As Clayton (Christensen, 1997), a Harvard Business Professor, called it an innovative distribution in The Innovator's Dilemma (Christensen, 1997). Disruption itself is a condition when a business is required to continue to innovate to keep up with developments so that it not only meets current needs but can also anticipate future needs (B. Prasetyo \& Trisyanti, 2019).

In the current era, disruption does not only apply to the business world. The disruption phenomenon has a profound effect of change in various fields. Disruption does not only change the business but the fundamentals of the business (Kasali, 2018). Starting from the cost structure to the culture, and even the ideology of an industry (Istiariani \& Arifah, 2020).

The business paradigm also shifted from the emphasis of owning to sharing (collaboration) (Prasetyo \& Sutopo, 2018). The phenomenon of disruption is not only happening in the business world, it has also expanded 
into other fields such as education, government, culture, politics, and law. In the political field, for example, political movements to gather people through mass concentration have been replaced by social media-based movements. The government sector is now also challenged to carry out bureaucracy effectively, efficiently based on one governance (Hopkins, 2011).

The cultural sector was also disrupted. The development of massive social media has reconstructed the cultural structure of society (Istifadah \& Senjani, 2020). Social relations of community relations are now more closely developed in cyberspace so that relationships in the real world become relatively less. Finally, the legal sector is now also disrupted. Legal regulations must also follow the development of existing technology, such as when the ministry of transportation had difficulty applying rules to provide standardization of online transportation. In short, disruptive regulation will occur disruptive regulation, disruptive culture, disruptive mindset, and disruptive marketing (Kasali, 2018).

\section{Research Methods}

This research uses descriptive qualitative study of literature. Qualitative research is specific to the understanding of social problems based on real conditions that are complex and detailed (Indrianto \& Supomo, 2016). Descriptive method is a method focusing on examining a group of people, an object, a condition, a thought, or an event in the present that aims to describe or explain accurately, factually, and systematically about facts, traits and relationships between phenomena researched. Literature study means data collection techniques by making a study of books, literature, notes, and reports related to the problem being studied (Fleeson et al., 2017). Researchers' motivation to use descriptive qualitative research methods for the literature study is because the foundation for carrying out qualitative research is oriented to pre-existing theories. 
Sharia accounting on Indonesian Financial Accounting Standard on ...

\section{Results and Discussion}

\section{The Role of Social Science}

The disruption has changed the world order rapidly. This change no longer takes thousands of years, as explained by Charles Darwin's theory of evolution in the Origin of Species (Darwin, 2004). Changes now only require a very short time. In such fast-paced situation, what changes is not only the phenomenon, for example, offline to online, but also the real world becoming a virtual world, printed media becoming social media, and so forth. Also, values, social order, and culture experience changes (Deacon, 2000).

The shift in values is reflected in the rise of various events that have recently taken place. The most pronounced impact is occurring in the environmental and social fields. Data from the Ministry of Environment and Forestry (KLHK) between July 2016-June 2017 shows that there has been a deforestation of 497,000 hectares or $64.3 \%$ of the total forests in Indonesia. Although KLHK claims a decline from 2014 of $73.6 \%$, this number is still quite large, compared to USA, which is an industrial country, that is able to maintain deforestation of no more than 200,000 hectares per year. Not only the environmental problems, Indonesia is categorized as the fourth dirtiest country in the world, according to the 2015 International Earth Science Information Network (Mangunjaya, 2008).

The damage to nature is caused by waste from the production process. In addition, there is a shift in the human paradigm in looking at nature (Nugroho \& Prasetyo, 2018). In this case, Max Weber states that since modernity has proliferated, humans have only used "instrumental reason" which then treats nature as something that can be manipulated, and can be directed (Schecter, 2010). As a result, the modern world and ecological damage are fast interlocking. Humans, while being separated from nature, live in another reality. This alienation makes the relationship between man and nature is as subject and object: human (subject) who controls nature (object) (Prasetyo \& Trisyanti, 2019). 
In addition to impacting on environmental issues, the Industrial Revolution also creates issues related to the loss of social values in the humanities. The millennial generation, the generation born around 19802000s, have shown symptoms of mental degradation. The consumerism lifestyle, unlimited freedom, and the loss of ethical behavior on social media are a series of examples of this degradation (Bennett, 2012). Rhenald Kasali refers to millennial as the strawberry generation, which is described as an attractive generation, but fragile because it does not have a strong mentality and values (Kasali, 2018).

The initial spirit of technological advancements is to facilitate human life. Since the invention of the machine and the start of the automation era, production has doubled, cutting time and cost (Noble, 2017). However, in the end, all these conveniences pose a big impact on humans, because the use of human labor is significantly reduced, resulting in an increase in the number of unemployment. Right at this point, it is necessary to have a development paradigm that not only enhances human capability in technology but also improves the mentality of its people (Stiglitz, 2002).

In the effort to build the character, the role of social science in humanities is needed. It is unfortunate, on several occasions, humanities are considered second class science lacking a significant impact in the era of the Industrial Revolution 4.0. Explored further, the development of science producing technological advances today starts from the rationality that is trained by humanities. The movement was reflected when the birth of modern times in the century around XVII (Hardiman, 2004). In that era, the era of awakening ratios had begun, allowing humans to think free of the theological doctrines that were once bounded (Fogel, 2000).

In the XVIII century, there was a substantial change in the way of human thinking which is marked by the secularization of knowledge resulting in the separation between the study of body and soul. Parts of the body are treated as material and are explained as the case of natural phenomena. Natural science is separated from social science and humanities. Towards the end of 
the twentieth century, advances in science and technology accelerated so that life and livelihood technology was created (T. Jacob, 1988)

Technology develops itself and becomes increasingly segregated, and is far from religion and ethics, law, social science, and humanities (Latour \& Venn, 2002). Therefore, there must be an effort to equate technology education with humanities. Knowledge about nature and life is incomplete without the knowledge of why something happens, how it happens, how the next development happens and how it should happen. Hard technology is incomplete without soft technology (T. Jacob, 1988).

\section{Accounting and Changes}

There is a major change in the business environment and accounting profession. The dynamics that take place in the supra system of technological environment, politic, economic, and social level that interact with each other in a very complex fabric are transforming the industrial society into an information society or knowledge society. Changes in the supersystem will certainly have a major impact on the internal business environment increasingly promoted lately, the transformation process in organizations and management, from corporate governance to a "hierarchical, mechanistic, autocratic and confrontational" structure to a "networked, organic, participatory and coexistence" structure (Prakarsa, 1996).

The changing which involves vision, mission, and strategy, as well as the further adaptation in culture, structure, and system that goes well in the development of micro and macro organization's environmental impact was very big on the accounting carrying accountability and decision support functions in ideology, politics, economy and social environment (Inanna \& Rahmatullah, 2018). In an environment where the change is no visible, the transformations that occur in the internal environment of the accounting profession-such as the expansion of technical standards both domestically and internationally, the expansion of the range of services offered, improvement of educational requirements, tightening of quality control, improvement of work responsibilities, and academic support-are 
contemporary challenges faced by the accounting profession which are likely to continue in the future. In his paper entitled "Infoteracy", Drucker stated that companies generally have two information systems. The first system is organized around external data flows and the other system that is much older and organized around internal data flows is the accounting system. Despite being 500 years old, the appearance of the accounting system today is still very chaotic (Indrajit, 2000).

The changing in information technology for the next 20 years, according to Drucker, is nothing compared to the changes that will occur in accounting. Furthermore, it was also stated that improvements were taking place in manufacturing cost accounting which had been in the status quo position since the 1920s until today (Hesselbein \& Goldsmith, 2013). On the other hand, business accounting service still faces an unsolved problem due to the difficulty in linking expenditure with the results achieved. Finally, although today the system organized around external and internal data are still separated, according to Drucker's projections, they will merge in the future so that the top management does not only depend on financial accounting information systems that have been easily manipulated and only explain what has happened-not what will happen-but also in the information system in a broader sense (Drucker, 2012).

Accounting and other information practices that develop in the business world are accountability and decision support systems that can influence the expectations and behavior of stakeholders in the decision making process and actions intended to transform physical systems so that they have greater capability to face the increasingly fierce arena of competition in future. Furthermore, research in tertiary institutions, among others, is carried out by comparing what happens in the real world (physical systems) with models used in accounting practices (conceptual systems) to find skills, expertise, knowledge or contemporary professional orientation that is more conducive in the process of forming good governance (Emirzon \& others, 2006).

The problems have arisen as a result of some of the fundamental problems in corporate governance that include the supply and demand of 
accounting information which is incomplete and the high cost of monitoring to close the opportunity to present the financial statements more perfect (Sulastri et al., 2013). These problems are clearly the challenges that accounting education must face in general and accounting research in particular because in order to improve corporate governance, accounting experts must find solutions from three groups and in terms of regulation: (1) a better financial reporting system; (2) increasing the reader's knowledge in order to better understand financial statements; and (3) provide input to regulators in order to formulate regulations that can reduce market distortions caused by information asymmetry (Anwar, 2013).

The various weaknesses confirm that the development of accounting system is less adaptive to changes in the business environment. It must be recognized that the state of the art of accounting system that is known so far is the business infrastructure in the era of the Industrial Revolution that is mechanistic (Schmidheiny \& Timberlake, 1992). The system is no longer compatible with the infrastructure of the business environment in the era of information and communication revolution which tends to be more organic. In the contemporary environment, in addition to improving financial reporting in accounting, integration between internal and external information systems that Drucker projected in advance seems inevitable because of the tendency to: (1) simplify processes or exclude various activities that do not create added value; (2) foster collaboration of various cross-functional activities along the internal and external value chains that even cross national borders (co-operation); and (3) internalize information and communication technology into mechanistic systems that were previously implemented manually—demanding uniformity and compatibility of information systems (Drucker, 2012).

\section{The Challenges and Expectations of Sharia Accountants on Zakat and Waqf Accounting}

Furthermore, sharia accounting produces a formulation related to the basic objectives of financial statements (Triyuwono, 2006a) such as: the first 
is to provide information, both financial and non-financial. Financial information, in this case, is information generated from financial transactions, while non-financial information is information that cannot be quantified or is not related to finance (Wyatt, 2008). It can be in the form of mental assets such as the morality of employees, also spiritual assets, that is the level of devotion from the management and all existing employees. Surely these two things have not been touched in the report presented by modern accounting (Nicholls, 2009).

The second basic objective of Sharia Accounting Financial Statements is related to accountability (El-Halaby \& Hussainey, 2016). In this case, accountability in question is horizontal and vertical, where the horizontal is a form of accountability to fellow humans, that is internal company or external parties; whereas vertical accountability is how the financial statements can also be accounted for before God. Of course, it can reduce various interests, even potential fraud. Accounting information like this is certainly very much needed by any entity. So it is expected that it will increase relevant studies on sharia accounting, followed by the number of the existing application as well as subsystems and systems of sharia accounting (Harahap, 2002).

The subsystems in the sharia accounting system in particular and the sharia accounting information system in general will be more dominant in the future due to their function to produce knowledge workers who can provide support for other knowledge workers in the process of creating added value. If the profession of accounting that is therein sharia accountant can take advantage of the open wide opportunities, according to Elliott, no administrator of universities who will treat accounting as a marginal discipline as in the past. The role of accounting and sharia accounting will be increasingly vital in the future-vital to understanding what that was going on in the economy; vital to harmonize conflicts of interest between the stakeholders; vital for production, consumption, savings and investment decisions; vital in the management of both business in general and aspects of business in a nonprofit organization, including university; and as has been alluded to in advance, vital for good corporate governance. Vitality of 
accounting information system seems to be redundant without being followed by revitalization of accounting system (Nurdiantini et al., 2016). But on the contrary, in the positive sense, the era of digitalization potentially increases the power of work just as much as 2.1 million up to the year 2025 meaning that there is a large selection of various professions and jobs. Besides, automation and digitalization can reduce the potential for carbon emissions by 26 billion metric tons (Gap, 2017).

Based on the elaboration of the characteristics and the focus of the industry 4.0, it is clear that the position of the profession of accountants and therein sharia accountant must keep up with the faster rhythm than the revolution. In coping with the changes, accountants will face: (1) Signal admit to noise. Accountants are already aware of threats and will be ready to take advantage of the momentum of the opportunities from the threats; (2) Ongoing changes. Accountants and sharia accountants already feel a change in their activities but feel no need to take a stand because they have not been disturbed by the "status quo". (3) The inevitable transformation. Accountants have been doing changes because the performance of "status quo" has been disrupted by the revolution and accountants should do the transformation changes with rapid and the best methods only for aspects that are deemed necessary. (4) Adapting to the new normal. The transformation of the accounting profession as a whole according to the demands of the new industry 4.0 model or the accounting profession will be lost if it is unable to adapt to these changes (Iswanto \& Wahjono, 2019). From the explanation of the position of accountant above, it would appear the challenge and influence of the profession of accountants and sharia accountants, among others, where the development of technology changes business significantly as many assets are in the form of "technology" and not physically tangible, not much need a source of humans power including accounting staff, companies do not have the concept of "place" or "premises" because it is controlled through the "virtual office" and how to market and sell through "market place" or "online store" that all of them have to be heading to a point of balance or equilibrium new which later form their standards (Noviari, 2009). 
In the past five years where technology 5G in devices of telecommunications has been fully adopted (Hidayat \& Herdin, 2018), access to the Internet in gigabyte speed per second and the device and also humans are already connected to one another both in IOT or IOP, the roles of accountants and sharia accountants have been changed. They are replaced by AI (Artificial Intelligence) technology and robotics to do the work of basic accounting to record, process, and sort out transactions, do automation of making financial statements and simultaneously analyze financial reports independently without human interference (Iswanto \& Wahjono, 2019).

The pattern of self-management functions of basic accounting and sharia accountants here will increase the efficiency and effectiveness of the work and the results are immediately known when it is also real-time (Рахуба, 2019). Many companies have been developing this system because they are already supported by the standardized process of financial management and standardized architecture of information system that are adequate and appropriate to meet the demands of industrial generation 4.0. Therefore, the crucial competences that are required for the accountants are the ability to analyze data, keep up with the development of information technology, and update the style of leadership (Milosevic \& Patanakul, 2005).

The further impact is the accountant and sharia accountant, as well as office accountant, will be "forced" to develop mobile applications to be able to access the data directly from devices like handphone, tablet and virtual reality (VR). Financial report auditing is done based on the real-time where regulators and auditors generate data that are needed automatically and directly from the system and sensors attached to the operational activities so that the transparency and accuracy of the data can be accounted for justification (Alam et al., 2019). If the accountant does not have the expertise that is adequate in the technology of information, another profession can take over the functions of accountants. So, it can be said that information technology is a principal need that an accountant must learn and understand. It is also expected that all people to be part of the change. It is also a pressure for educational institutions to create a curriculum that is relevant for students 
of accounting to adjust with digital connectivity so it is expected the graduates who will be the accountant can adapt to the digital age (Kurunmäki, 2004).

Era changes indeed are inevitable. Therefore, it is important to have the ability to control the reaction and attitude to the change of order to move forward with the times (Handy, 2011). In the sector of accounting, the various challenges that arise with the advent of the digital era cannot be ignored, so they must be studied properly to determine the attitude to overcome them. Being fluent in technology is one of the keys to facing challenges in this era.

\section{The Sharia Accountants Profession Understands IFAS 109 on ZIS Accounting and IFAS 112 on Waqf}

Zakat is one of the five pillars of Islam that must be implemented. Zakat is useful for people to purify the assets they obtain. Zakat can also be regarded as a tax which has a spiritual connotation (Gambling \& Karim, 1986)(Karim, 1990). In the economic and social context, zakat is intended to achieve social justice (Sarif \& Kamri, 2009). To collect zakat, infaq and shadaqah funds, the ploriferation of amil zakat bodies aims to facilitate people to distribute zakat, infaq and shadaqah funds.

The financial statements become one of the media for operational responsibility of BAZIS in collecting and distributing zakat, infaq and sedekah (ZIS) funds (Nurlinda et al., 2019). For financial statements to be accountable and transparent, the accounting standards that govern them are needed. It is different from Islamic entities that the activities of collecting and distributing ZIS funds are also carried out in the context of social functions other than commercial functions (Sapingi et al., 2014), so that the financial statement components contained in IFAS 101 also have reports on the sources and uses of ZIS funds (Nurlaila, 2015). BAZIS was established specifically only for managing ZIS funds, so the preparation of its financial statements does not adhere to IFAS 101 but uses IFAS 109 as the accounting standards governing zakat and donation/sadaqah. Of course things that are not regulated in IFAS 109 can use the relevant IFAS as long as it does not conflict with Islamic 
sharia. These show the different components in IFAS 101 and IFAS 109 (Pertiwi et al., 2017).

The sharia accountant profession understands IFAS 112 on Waqf Accounting in modern time (Maulana, 2019). One of the forms and movements of waqf that has received the attention of scholars and scholars is cash waqf. In the history of Islam, cash waqf flourished well in the days of the Mamluks and Ottoman Turks (Arif \& Purwanto, 2020). But only recently has it become the subject of intense discussion among Islamic economists and scholars. In Indonesia, the discussion and study produced encouraging results, that are the inclusion and regulation of cash waqf in Indonesian legislation through Law No. 41 of 2004 on Waqf. As such, cash waqf has been recognized in positive law in Indonesia (Hidayatul Ihsan M, 2007).

In general, IFAS 112 regulates the accounting treatment of waqf transactions conducted both by Nazhir and the endowments in the form of organizations and legal entities. IFAS 112 can also be applied by Nazhir individuals (IAI, 2020).

Management and development of waqf is a reporting entity (the term 'waqf entity' is used) which compiles separate financial statements and is not consolidated into the financial statements of organizations or legal entities of Nazhir. The financial statements of waqf entities do not consolidate the financial statements of a subsidiary. The complete financial statements of waqf entities include statements of financial position, detailed reports of waqf assets, activity reports, cash flow statements, and notes to financial statements (Fahham, 2015).

The basis for the recognition of perennial assets is the waqf pawning deed, where the waqf and wa'd do not meet the criteria for recognizing of waqf assets. Temporary waqf is a liability that must be returned to the future waqif. The basis for acknowledging the distribution of the benefits of waqf is the acceptance of the benefits of the waqf by mauquf alaih; while the basis for Nazhir rewards is the net result of the management and development of waqf assets that have been realized in the form of cash (cash basis). The 
Sharia accounting on Indonesian Financial Accounting Standard on ...

measurement of waqf assets received from waqif is the nominal value for cash and the fair value for non-cash assets (Hidayatul Ihsan M, 2007).

\section{The Professional Solutions for Sharia Accountants in the Industrial Revolution}

\section{0 and Society 5.0}

JIAFR | 249

The solutions to reduce the problems in the application of IFAS 109 on ZIS Accounting and IFAS 112 on Waqf Accounting in the face of the industrial and public revolution 5.0 include: (1) Improve the intention and maintain public trust because the ZIS and Asset Waqf and Productive Waqf funds are only entrusted to be sent; (2) Improve management structure and management of ZIS management and management of Waqf, because there are still a number of ZIS management and Waqf management considered as minor; (3) Maximizing the Zakat Organization Forum (FOZ) in the regions to work together so that they can exchange knowledge and information, both from government regulations to reporting on muzaki and Waqf Board and also must report to the public in the management of endowments, either productive or cash waqf; (4) The use of IFAS 109 training is intended for all BAZIS financial managers or financial staff so that financial reporting can be well structured and results in increased BAZIS accountability and IFAS 112 training aimed at waqf managers; and (5) For BAZIS already having sufficient amil funds, it is recommended to have special software for financial reports so as to facilitate accounting in reporting as well as for Indonesian Waqf Body (Badan Wakaf Indonesia/BWI) or the Waqf Manager having a computerized or Android-based Waqf Management Information System (MIS).

\section{Three Sharia Accounting Skills to Zakat and Waqf Accounting Needed to Face the Industrial Revolution of Era 4.0 and Society 5.0}

The Industrial Revolution 4.0 drives the latest trends in automation and data exchange a global phenomenon. For welcoming this new era, the government has carried out a number of policies. There are three basic skills or abilities to be activated in a balanced manner in every human being so that 
the future generation will emerge capable of facing the Industrial Revolution 4.0, especially in the field of sharia accounting (Mahnkopf, 2019).

The three basic capabilities of sharia accounting of zakat and waqf that JIAFR | 250 must be developed are; first, the life skills of Islamic accounting which will enable the self understanding and the responsibilities to the social environment (Pramanik et al., 2015); second, learning and innovation skills of Islamic accounting of zakat and waqf which will enable to think creatively, critically and solve complex problems, be able to collaborate, and communicate effectively in the field of Islamic accounting; third, sharia accounting of zakat and waqf literacy skills that will enable a variety of knowledge and technology to solve everyday problems encountered.

\section{Conclusion}

Renald Kasali concluded that the era of disruption is a threatening period posing severe challenges to human life, and people who are unable to adapt to change will certainly experience difficulties in wading through the tide of daily life that is full of changes and full of competitions (Kasali, 2018). Globalization is not only a phenomenon affecting the field of technology, but has disrupted other various fields such as social, legal, and economic. As a result of this disruption, the world order has changed drastically. The era of the Industrial Revolution 4.0 which offers convenience and speed makes people become super fast. Technology is used and developed to accelerate the achievement of every goal set by humans. In the end, the material and psychological needs become inevitable to ignore, and it will surely increase. The industrial revolution is now entering the fourth phase. The rapid development of science and technology has a substantial impact on human life. Conveniences and innovations are obtained by the support of digital technology. Services are faster and more efficient and have a wider range of connections with online systems. Life is easier and cheaper. Professional accountants and sharia accountants need a pattern of self-management of sharia accounting basic functions which will certainly increase the work efficiency and effectivity with real-time results. Several companies develop 
this because it is supported by the standardization of financial management processes and standardization of information systems architecture which is adequate and in line with the demands of the fourth generation industry following the crucial competencies needed for accountants. Digitalisation, computing power and data analytics have given birth to remarkable breakthroughs in various fields that disrupt our lives and our civilization, which changes the global, national and regional economic and political landscape.

The sharia accountants must understand and master IFAS 102 on ZIS accounting and IFAS 112 on waqf accounting and balance the knowledge of ZIS MIS and waqf that is updated with the current information technology.

\section{References}

Agung, A. M. L. (2013). Human Capital Competencies. Elex Media Komputindo.

Alam, N., Gupta, L., Zameni, A., \& others. (2019). Fintech and Islamic Finance. Springer.

Anwar, A. A. (2013). Analisis Perspektif Stakeholder Terhadap Implementasi Corporate Social Responsibility (Csr). Jurnal Skripsi Universitas Hasanuddin Makassar. (Unpublished Research Journal).

Arifson, H. (2020). Analisis Penerapan Akuntansi Wakaf Berdasarkan Indonesian Financial Accounting Standard 112 Pada Yayasan Wakaf Indo As-Sakinah Al-Mawaddah Kota Pekanbaru (Doctoral dissertation, Universitas Islam Negeri Sultan Syarif Kasim Riau).

Arwani, A. (2017). The Future of The Profession of Accountant Sharia Enter MEA In 2017. International Journal of Islamic Business and Economics (IJIBEC), 1(1), 31. https://doi.org/10.28918/ijibec.v1i1.777.

Arwani, A. (2018). Issues and Challenges of Shariah Auditing in Islamic. 18(2), 169-186.

Ather, S. M., \& Ullah, M. H. (2009). Islamic Accounting Systems and Practices. The Cost and Management, 2000, 2009.

Arif, A., \& Purwanto, A. (2020). Analisis Pengaruh Islamic Corporate Governance terhadap Manajemen Laba pada Bank Umum Syariah di Indonesia dan Malaysia. Permana: Jurnal Perpajakan, Manajemen, Dan Akuntansi, 12(2), 183-195. 
Agus Arwani

Bennett, W. L. (2012). The personalization of politics: Political identity, social media, and changing patterns of participation. The Annals of the American Academy of Political and Social Science, 644(1), 20-39.

JIAFR | 252

Budiman, A. (2019). Kolom pakar: Industri 4.0 vs Society 5.0. FT UGM. https://ft.ugm.ac.id/kolom-pakar-industri-4-0-vs-society-5-0/

Burange, A. W., \& Misalkar, H. D. (2015). Review of Internet of Things in development of smart cities with data management \& privacy. 2015 International Conference on Advances in Computer Engineering and Applications, 189-195.

Cooper, W. J., Cooper Jr, W. J., \& Terrill, T. E. (2009). The American South: A History (Vol. 2). Rowman \& Littlefield.

Darwin, C. (2004). Origin of Species. Edison. NJ: Castle Books.

Deacon, B. (2000). Globalization and social policy: The threat to equitable welfare (Issue 5). Geneva 2000 Occasional Paper.

Drucker, P. (2012). Management challenges for the 21st century. Routledge.

El-Halaby, S., \& Hussainey, K. (2016). Determinants of compliance with AAOIFI standards by Islamic banks. International Journal of Islamic and Middle Eastern Finance and Management, 9(1), 143-168. https://doi.org/10.1108/IMEFM-06-2015-0074.

Emirzon, J., \& others. (2006). Regulatory Driven Dalam Implementasi PrinsipPrinsip Good Corporate Governance Pada Perusahaan di Indonesia. Jurnal Manajemen \& Bisnis Sriwijaya, 4(8), 93-114.

Fahham, A. M. (2015). Cash Waqf Management at The Waqf and Land Management Agency Nahdlatul Ulama Special Region of Yogyakarta. Aspirasi, 6(1), 27-36.

Fleeson, W., Jayawickreme, E., Jones, A. B. A. P., Brown, N. A., Serfass, D. G., Sherman, R. A., Mestdagh, M., Pe, M., Pestman, W., Verdonck, S., Kuppens, P., Tuerlinckx, F., O’Connor, M. C., Paunonen, S. V, Baumert, A., Schmitt, M., Perugini, M., Johnson, W., Blum, G. S., ... Matyjek-, M. (2017). pengaruh islamic social responsibility dan islamic governance terhadap kinerja dan reputasi bank syariah indonesia. Journal of Personality and Social Psychology, 1(1), 1188-1197. https://doi.org/10.1111/j.1469-7610.2010.02280.x.

Fogel, R. W. (2000). The fourth great awakening and the future of egalitarianism. University of Chicago Press. 
Fukuyama, F. (2017). The great disruption. Profile Books.

Gambling, T. E., \& Karim, R. A. A. (1986). Islam and 'social accounting'. Journal of Business Finance \& Accounting, 13(1), 39-50.

Gap, G. G. (2017). World economic forum. Cologny/Geneva.

Ghufron, M. A. (2018). Revolusi industri 4.0: Tantangan, Peluang dan Solusi Bagi Dunia Pendidikan. Seminar Nasional Dan Diskusi Panel Multidisiplin Hasil Penelitian Dan Pengabdian Kepada Masyarakat.

Hamdan, H. (2018). Industri 4.0: Pengaruh Revolusi Industri Pada Kewirausahaan Demi Kemandirian Ekonomi. Jurnal Nusantara Aplikasi Manajemen Bisnis. https://doi.org/10.29407/nusamba.v3i2.12142.

Handy, C. (2011). Beyond Certainty: the changing worlds of organisations. Random House.

Harahap, S. S. (2002). The Disclosure of Islamic Values-Annual Report The Analysis of Bank Muamalat Indonesia's Annual Report. Jurnal Iqtisad, 3(1).

Hardiman, F. B. (2004). Filsafat modern: dari Machiavelli sampai Nietzsche. Gramedia Pustaka Utama.

Harto, K. (2018). Tantangan Dosen PTKI di Era Industri 4.0. Jurnal Tatsqif, 16(1), 1-15.

Hesselbein, F., \& Goldsmith, M. (2013). The leader of the future 2. Elex Media Komputindo.

Hidayat, R., \& Herdin, E. L. (2018). Key Potential Analysis of 5 G Technology for Optimal Implementation: Case Study in West Java.

Hidayatul Ihsan M. (2007). Towards the Improvement of Waqf Accountability in Indonesia : A Critical Review of the Act No 41 / 2004 on Waqf. Jumal Akuntansl \& Manajemen, 2(2), 71-80.

Hopkins, A. G. (2011). Globalisation in world history. Random House.

Hurst, C. E., Gibbon, H. M. F., \& Nurse, A. M. (2016). Social inequality: Forms, causes, and consequences. Routledge.

IAI. (2020). Akuntansi Wakaf telah disahkan. IAI Global. http://www.iaiglobal.or.id/v03/berita-kegiatan/detailberita1074=de-Indonesian Financial Accounting Standard-112-akuntansiwakaf-telah-disahkan\#. 
Agus Arwani

Inanna, I., \& Rahmatullah, R. (2018). Wajah Perekonomian Indonesia (Vol. 1, Issue 1). Badan Penerbit Universitas Negeri Makassar.

Indrajit, R. E. (2000). Manajemen sistem informasi dan teknologi informasi. Jakarta: PT Elex Media Komputindo.

JIAFR | 254 Indrianto, \& Supomo. (2016). Metodologi Penelitian Bisnis untuk Akuntansi dan Manajemen. In Yogyakarta: Penerbit BPFE. https://doi.org/10.1016/S1571-0866(07)80050-9.

Islamiyah, U. N. (2020). Implementasi Indonesian Financial Accounting Standard 112 pada nazhir Universitas Airlangga (Doctoral dissertation, UIN Sunan Ampel Surabaya).

Iswanto, A. C., \& Wahjono, W. (2019). Pengaruh Revolusi Industri 4.0 Terhadap Ilmu Akuntansi--Esai. INFOKAM, 15(1).

Istifadah, R. U., \& Senjani, Y. P. (2020). Religiosity as the moderating effect of diamond fraud and personal ethics on fraud tendencies. Journal of Islamic Accounting and Finance Research, 2(1), 91-116. https://doi.org/10.21580/jiafr.2020.2.1.4712.

Istiariani, I., \& Arifah, U. (2020). Education Level, Spiritual Intelligence, and Love of Money: Do They Correlate to Ethical Perception?. Shirkah: Journal of Economics and Business, 5(2), 228-249.

Karim, R. A. A. (1990). The independence of religious and external auditors: The case of Islamic banks. Journal of Accounting, Auditing and Accountability, 3(3), 34-43.

Kasali, R. (2018). Strawberry Generation. Mizan.

Kemeristekdikti. (2018). Pengembangan Iptek dan Pendidikan Tinggi di Era Revolusi Industri 4.0. Ristekdikti.

Keoh, S. L., Kumar, S. S., \& Tschofenig, H. (2014). Securing the internet of things: A standardization perspective. IEEE Internet of Things Journal, 1(3), 265-275.

Kurunmäki, L. (2004). A hybrid profession-the acquisition of management accounting expertise by medical professionals. Accounting, Organizations and Society, 29(3-4), 327-347.

Latour, B., \& Venn, C. (2002). Morality and technology. Theory, Culture \& Society, 19(5-6), 247-260. 
Lenap, I. P. (2019). Pengungkapan Pendapatan Non-Halal: Indonesian Financial Accounting Standard109 Vs Praktik. Jurnal Aplikasi Akuntansi, 3(2), 94-116.

Mahnkopf, B. (2019). The '4th wave of industrial revolution'-a promise blind to social consequences, power and ecological impact in the era of 'digital capitalism'.

Mangunjaya, F. M. (2008). Bertahan di bumi: gaya hidup menghadapi perubahan iklim. Yayasan Pustaka Obor Indonesia.

Maulana, A. O. (2019). Legitimacy dynamics of accounting standards setting: the case of Indonesia. University of Reading.

Mayasari, D. (2019). Mengenal Society 5.0, Transformasi Kehidupan yang Dikembangkan Jepang. Jakarta: www.timesindonesia.co.id. Interview Guidelines.

Milosevic, D., \& Patanakul, P. (2005). Standardized project management may increase development projects success. International Journal of Project Management, 23(3), 181-192.

Mustaqim, M., \& Bahruddin, A. (2015). Spirit Gusjigang Kudus dan Tantangan Globalisasi Ekonomi. Jurnal Penelitian, 9(1).

Nicholls, A. (2009). 'We do good things, don't we?':'Blended Value Accounting'in social entrepreneurship. Accounting, Organizations and Society, 34(6-7), 755-769.

Niemueller, T., Zwilling, F., Lakemeyer, G., Löbach, M., Reuter, S., Jeschke, S., \& Ferrein, A. (2017). Cyber-physical system intelligence. In Industrial Internet of Things (pp. 447-472). Springer.

Noble, D. (2017). Forces of production: A social history of industrial automation. Routledge.

Noviari, N. (2009). Pengaruh Kemajuan Teknologi Informasi Terhadap Perkembangan Akuntansi. Jurnal Ilmiah Akuntansi Dan Bisnis.

Nugroho, Y., \& Prasetyo, A. (2018). Assessing information systems success: A respecification of the DeLone and McLean model to integrating the perceived quality. Problems and Perspectives in Management, 16(1), 348-360. https://doi.org/10.21511/ppm.16(1).2018.34.

Nurdiantini, D., \& Others. (2016). Pengaruh Partisipasi Pengguna Terhadap Kualitas Sistem Informasi Akuntansi. A survey on 3 Airlines Companies 
Agus Arwani

(Sriwijaya Air, Lion Air, dan Kalstar Aviation) di Bandung. Fakultas Ekonomi Unpas.

Nurlaila, N. (2015). Islamic accounting concept in al-Qur'an and its implementation in Indonesia.

Nurlinda, M. Z., Salimi, F., Umar, Z., \& Mulyadi, J. F. (2019). Accounting and Management of Zakat, Infak/Sedekah (Case Study of Zakat Institutions in Medan City).

Nugroho, L., Harnovinsah, H., Putra, Y. M., \& Prinoti, P. (2020). Analysis of Comparison of Islamic Banks with Online Micro In Disbursements of Micro-Financing Based on Requirements, Services Speed and Margin (Case Study of Micro-finance at Bank Mandiri Syariah and Micro Credit Uangteman.com). Journal of Islamic Economics and Social Science (JIESS), 1(1), 1-10.

Pertiwi, R. A., Kholmi, M., \& Kurniawati, E. T. (2017). Analisis Penerapan Akuntansi Dana Zakat dan Infak/sedekah pada Lembaga Amil Zakat Infak, dan Shodaqoh Muhammadiyah (Lazismu) Kabupaten Malang. Jurnal Reviw Akuntansi Dan Keuangan, 5(2).

Prakarsa, W. (1996). Transformasi pendidikan akuntansi menuju globalisasi. Konvensi Nasional Akuntansi III. Jakarta: Ikatan Akuntansi Indonesia.

Pramanik, A. H., Mohammed, M. O., Haneef, M. A., Amin, F. M., Muhammad, A. D., Dabour, N., \& Bağcl, K. (2015). Integration of waqf and Islamic microfinance for poverty reduction: Case studies of MAlaysia, Indonesia and Bangladesh. In SESRIC \& IIUM. https://doi.org/10.1017/CB09781107415324.004.

Prasetyo, B., \& Trisyanti, D. (2019). Prosiding SEMATEKSOS 3 "Strategi Pembangunan Nasional MenghadapiRevolusiIndustri 4.0" REVOLUSI INDUSTRI 4.0. Revolusi Industri 4.0 Dan Tantangan Perubahan Sosial.

Prasetyo, H., \& Sutopo, W. (2018). Industri 4.0: Telaah Klasifikasi Aspek Dan Arah Perkembangan Riset. J@ti Undip: Jurnal Teknik Industri. https://doi.org/10.14710/jati.13.1.17-26

Purwandini, D. A., \& Irwansyah, I. (2018). Komunikasi Korporasi Pada Era Industri 4.0. Jurnal Ilmu Sosial, 17(1), 53-63.

Rahman, T. (2015). Akuntansi Zakat, Infak dan Sedekah (Indonesian Financial Accounting Standard 109): Upaya Peningkatan Transparansi dan Akuntabilitas Organisasi Pengelola Zakat (OPZ). Muqtasid: Jurnal Ekonomi dan Perbankan Syariah, 6(1), 141-164. 
Ristekdikti. (2018a). Era Revolusi Industri 4.0 Saatnya Generasi Millenial Menjadi Dosen Masa Depan. Sumber Daya IPTEK Dan DIKTI.

Ristekdikti, B. (2018b). "Era Revolusi Industri 4.0: Perlu Persiapkan Literasi Data, Teknologi dan Sumber Daya Manusia." Belmawa.Ristekdikti.Go.Id. https://doi.org/10.1146/annurev-statistics-060116-054017

Roblek, V., Meško, M., \& Krapež, A. (2016). A complex view of industry 4.0. Sage Open, 6(2), 2158244016653987.

Sapingi, R., Obid, S. N. S., \& Nelson, S. P. (2014). Towards developing a disclosure index for Malaysian Zakat Institutions. The Journal of Muamalat and Islamic Finance Research, 204(3538), 1-25.

Sari, A. F. K., Triyuwono, I., \& Djamhuri, A. (2016). Pragmatic on Islamic Accounting Education. Imperial Journal of Interdisciplinary Research, 2(11), 1033-1037.

Sarif, S., \& Kamri, N. (2009). A theoretical discussion of zakat for income generation and its FIQH issues. Shariah Journal, 17(3), 457-500.

Schecter, D. (2010). The critique of instrumental reason from Weber to Habermas. Bloomsbury Publishing USA.

Schmidheiny, S., \& Timberlake, L. (1992). Changing course: A global business perspective on development and the environment (Vol. 1). MIT press.

Setiawan, W., Suud, F. M., Chaer, M. T., \& Rahmatullah, A. S. (2018). Pendidikan Kebahagiaan dalam Revolusi Industri 4. AL-MURABBI: Jurnal Studi Kependidikan Dan Keislaman, 5(1), 101-120.

Shahnaz, S. (2016). Penerapan Indonesian Financial Accounting Standard No. 109 tentang Pelaporan Keuangan Akuntansi Zakat, Infaq/Sedekah pada Badan Amil Zakat Provinsi Sulawesi Utara. Jurnal EMBA: Jurnal Riset Ekonomi, Manajemen, Bisnis dan Akuntansi, 3(4)..

Stiglitz, J. E. (2002). Participation and development: Perspectives from the comprehensive development paradigm. Review of Development Economics, 6(2), 163-182.

SULASTRI, L., \& others. (2013). Kajian Manajemen Berbasis Nilai Dalam Konteks Perguruan Tinggi (Studi Kasus Pada Perguruan Tinggi Binus University). UNPAS.

T. Jacob. (1988). Manusia, ilmu dan teknologi. Tiara Wacana Yogya.

Triyuwono, I. (2000). Organisasi dan Akutansi Syari'ah. LKIS. 
Agus Arwani

Triyuwono, I. (2006a). Akuntansi Syari'ah: Menuju Puncak Kesadaran Ketuhanan Manunggaling Kawulo-Gusti. Pidato Pengukuhan Jabatan Guru Besar.

Triyuwono, I. (2006b). Perspektif, Metodologi, dan Teori Akuntansi Syariah. PT. JIAFR | 258 RajaGrafindo.

Wyatt, A. (2008). What financial and non-financial information on intangibles is value-relevant? A review of the evidence. Accounting and Business Research, 38(3), 217-256.

Рахуба, В. И. (2019). Basics of Electronic Business and Marketing.

Yollanda, M., \& Adnan, M. A. (2018). Menuju Terbentuknya Indonesian Financial Accounting Standard (Pernyataan Standar Akuntansi Keuangan) Wakaf di Indonesia. Reviu Akuntansi dan Bisnis Indonesia, 2(2), 116-128. 